The Workfare State 
AMERICAN GOVERNANCE:

POLITICS, POLICY, AND PUBLIC LAW

Series Editors: Richard Valelly, Pamela Brandwein, Marie Gottschalk, Christopher Howard

A complete list of books in the series

is available from the publisher. 


\title{
The Workfare State
}

\author{
Public Assistance Politics
}

from the New Deal to the New Democrats

\section{Eva Bertram}

\author{
$\overline{\text { PENN }}$ \\ UNIVERSITY OF PENNSYLVANIA PRESS \\ PHILADELPHIA
}


Copyright (c) 2015 University of Pennsylvania Press

All rights reserved. Except for brief quotations used

for purposes of review or scholarly citation, none of this

book may be reproduced in any form by any means without written

permission from the publisher.

Published by

University of Pennsylvania Press

Philadelphia, Pennsylvania 19104-4112

www.upenn.edu/pennpress

Printed in the United States of America

on acid-free paper

13579108642

Library of Congress Cataloging-in-Publication Data

Bertram, Eva, author.

The workfare state : public assistance politics from the New Deal to the new Democrats / Eva Bertram.

pages $\mathrm{cm}$.-(American governance : politics, policy, and public law)

Includes bibliographical references and index.

ISBN 978-0-8122-4707-7 (hardcover : alk. paper)

1. Welfare recipients-Employment-United States-History-20th century.

2. Welfare recipients-United States-History-20th century. 3. Public welfarePolitical aspects-United States-History-20th century. 4. Welfare state-United States-History-20th century. 5. United States-Social policy-20th century.

6. United States-Politics and government-20th century. 7. Democratic Party (U.S.)-History-20th century. I. Title. II. Series: American governance. HV95.B456 2015

362.5' $840973-d c 23$ 